\title{
Climate change and social complexity in the Atacama Desert during the Late Quaternary
}

Antonio Maldonado', C.M. Santoro ${ }^{2}$ and Escallonia members ${ }^{3}$

\section{Prehistoric human groups in the Atacama Desert developed socio-cultural complexities despite living in the world's driest desert. Different technological adaptations were developed as part of their interactions with variable environments over the last 14,000 years.}

Human history can be understood as the constant mutual interaction between variable environments and social systems. It is the basis for many archaeological and socio-natural science studies worldwide and is particularly prominent in the Atacama Desert in northern Chile. Using an eco-anthropological perspective, we focus on identifying and explaining social continuities and discontinuities that occurred during key cycles of water availability since the first humans arrived, ca. $14 \mathrm{ka}$ ago, at the Pampa del Tamarugal (PdT), in the hyperarid core of the Atacama Desert (Fig. 1). The major trends of long-term history of human-environment interactions show that people developed different ways of living, to endure the desert even during the driest climatic periods instead of completely abandoning it or, even worse, suffering cultural collapse.

The first peoples in Pampa del Tamarugal and Tarapacá region (14-10 ka BP)

Ecosystems and human societies in the Atacama Desert have been constrained mainly by the lack of water. The first human occupation occurred at the end of the Pleistocene, during relatively moist periods (at 17.5-14 and 13-10 ka BP; Quade et al. 2008). In the PdT, these humid periods increased perennial stream discharge and groundwater tables, expanding riparian and wetland ecosystems into what is now
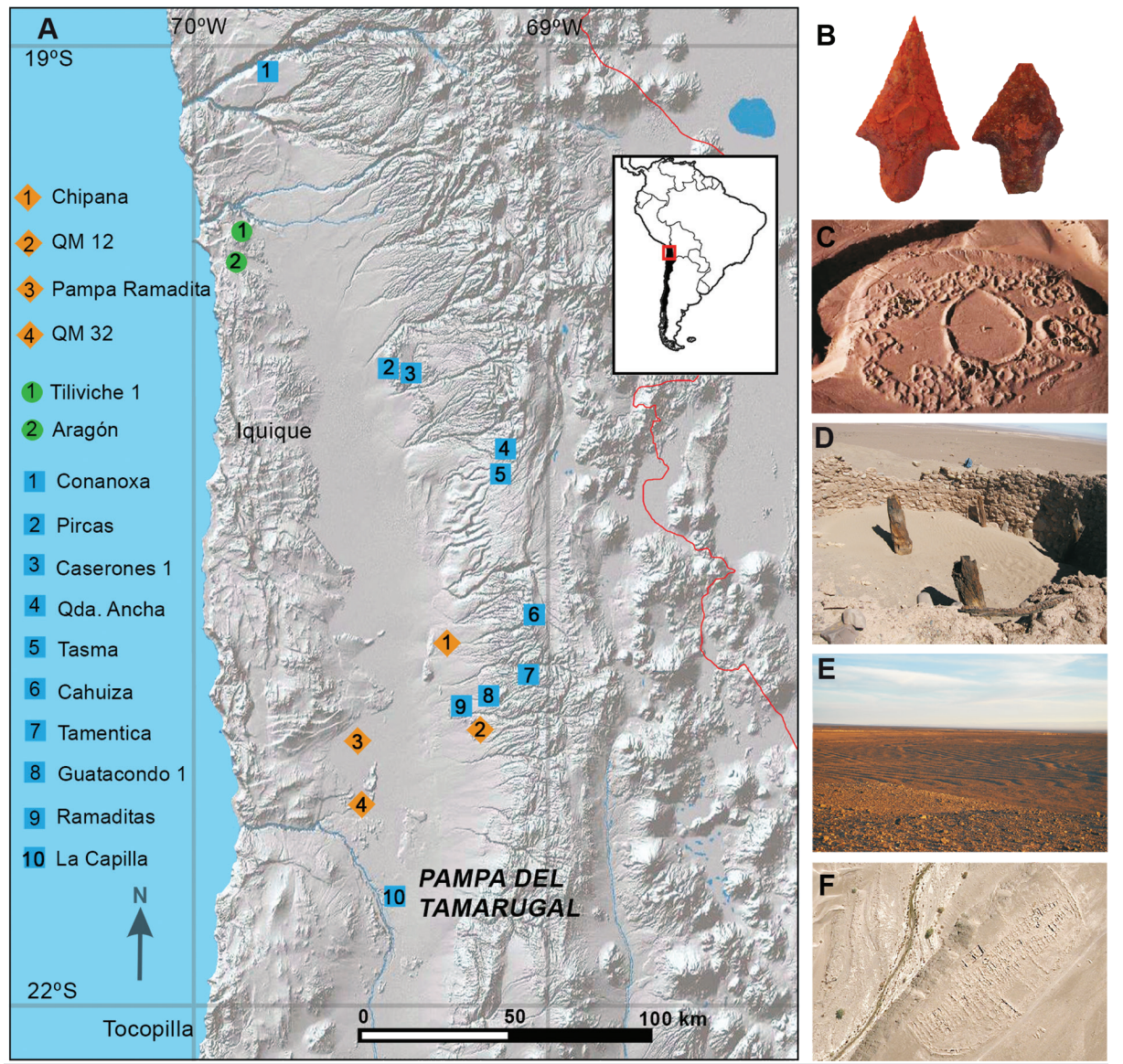

E
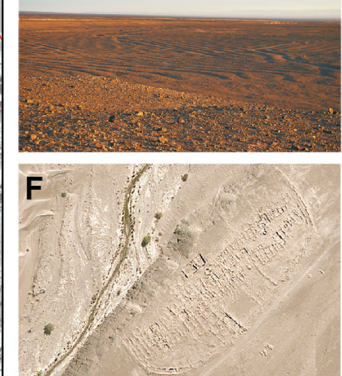

Figure 1: (A) Location of Early- (orange), Mid-Holocene (green) and Formative (blue) sites. (B) Late Pleistocene projectile points. (C, D, F) Formative villages. (E) Cropfields in Guatacondo. Red line shows today's border between Chile and Bolivia. the hyperarid core of the desert (Gayo et al. 2012; Fig. 2). During those humid periods, the desert became an attractive habitat for hunter-gatherers, plenty of camelids (i.e. guanacos and vicuñas), rodents and birds. The archaeological evidence shows human occupations next to paleowetlands surrounded by trees (i.e. Prosopis species parkland), the dry trunks of which are still preserved and visible on the surface of the desert (Santoro et al. in press; Fig. 1). Diverse contemporaneous open camps, like QM12 (Fig. 1 and 2), show complex hunting-gathering systems successfully adjusted to the ecosystems in the PdT, coupled with long-distance human interaction from the Pacific coast and the high Andes.

\section{Environmental stress and socio-} environmental discontinuity (10-3 ka BP) The beginning of the Holocene (ca. 10 ka BP) seems to have triggered drastic transformations in settlement patterns and cultural behavior that lasted for several millennia due to the establishment of fluctuating arid conditions in the southern Atacama Desert (Núñez et al. 2013; Fig. 2). Archaeological data show a phenomenon of socio-environmental discontinuity that has been conceptualized as the "silencio arqueológico" (archaeological silence; Núñez et al. 2013)

Particularly in the PdT, the onset of hyperarid conditions triggered ecological stress characterized by the dramatic reduction of productivity in the ecosystem. Accordingly, people possibly migrated toward more productive areas such as the coast, where sequences of continuous occupation began approximately $9 \mathrm{ka} \mathrm{BP}$, with complex ideological innovations, including artificial mummification (Marquet et al. 2012) and the development of a specialized technology focused on the exploitation of marine resources. More abundant settlements and the development of new technologies occurred along the coast since 7 ka BP (Castro et al. in press). The Altiplano, located eastwards of the PdT, was also productive as it may have been less vulnerable to climate change and maintained sustained environments (Ledru et al. 2013) and key locations for hunter-gatherers during the arid MidHolocene (Pintar 2014). Archaeological data 


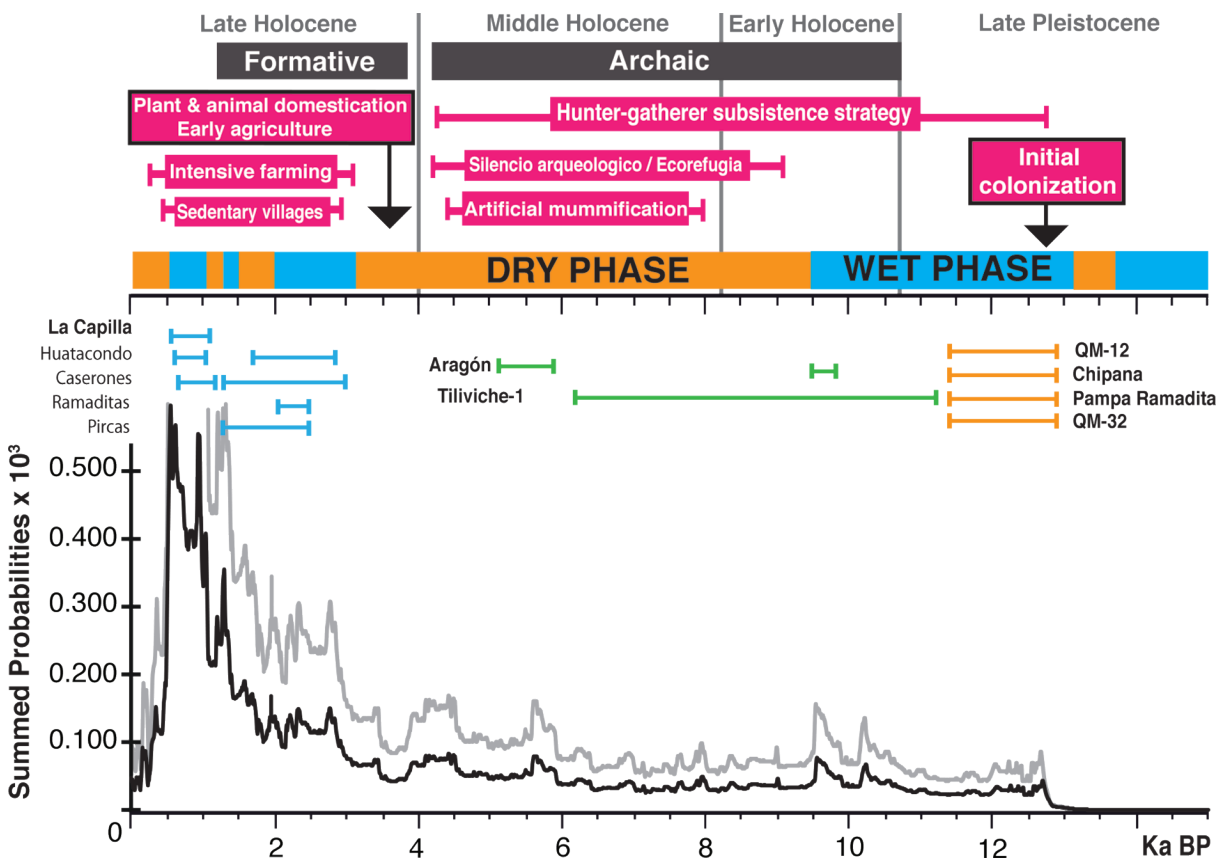

Figure 2: Paleoenvironmental and archaeological synthesis of the PdT since the Late Pleistocene showing human occupation modes, dry/wet phases, main archaeological sites (Fig. 1) occupation timing and occupation density (black line) measured through the summed probability ${ }^{14} \mathrm{C}$ ages from archaeological sites in the PdT. The grey line is a $2 x$ exaggeration of the black line. Modified from Santoro et al. (2016).

show intensification in occupation after $10 \mathrm{ka}$ BP. Other groups might have settled around local sources of permanent water within the PdT, or within narrow ravines such as Sapiga and Tiliviche canyons, whose archaeological sites (Aragón and Tiliviche 1; Fig. 1) point out that local ecosystems were complemented with protein from coastal resources (Santoro et al. in press).

Evidence from the central Atacama also shows, however, that populations rebounded after $6 \mathrm{ka} B \mathrm{P}$, meaning that the Mid-Holocene may not have been as dry as thought (Gayo et al. 2015; see Fig. 2).

\section{The return to the Pampa del Tamarugal (3-1 ka BP)}

In the late-Holocene in the PdT, between 2.5-0.7 ka BP, arid conditions gradually gave way to wetter climates, peaking between 2-1 ka BP (Maldonado and Uribe 2015; Fig. 2). The wet phase is partly coeval with the cultural Formative period (2.5-1.5 ka BP), which is characterized by an intensification of social complexity and diversification of communities. Large, dispersed or concentrated villages with monumental public spaces were founded. A wide range of innovative technologies (i.e. ceramic, textile and metal production) and landscape arrangements were added to the traditional hunting-gathering systems. This involved sophisticated technologies for managing surface water including water dams, irrigation canals and farmland. These innovations generated a concentration of population and social power (Urbina et al. 2012; see Fig. 1a), coupled with an increase in population size (Gayo et al. 2015; see Fig. 2).

\section{Internodal areas (1.0-0.5 ka BP) and} capitalism (0.5 ka BP - present day)

Aridity, which increased from 1.0 to $0.7 \mathrm{ka}$ $\mathrm{BP}$ and lasted until recent times, has been associated with sociopolitical turmoil and inequities (Uribe 2006). This resulted in massive population migrations to highland areas and the establishment of new and numerous settlements on the western slope of the Andes, since water resources in these areas were much more abundant and predictable (Maldonado and Uribe 2015; see Fig. 2). Consequently, new systems of agriculture (terraces and irrigation canals), strategic and defensive urban arrangements, and land management were developed. Increasingly circumscribed territories were managed by societies of "segmented" organizations (social groups independently organized). Thus, the PdT was transformed into an inter-nodal territory crossed by trains of llama caravans that connected the highlands with the coast.

During the Inca State regime (0.5-0.4 ka BP), the scale and organization of mining exploitation of copper and silver ore became important; thus, previous socio-economic systems were restructured for metal production (Zori and Tropper 2010). Traditional activities (i.e. agriculture, herding and foraging) gradually increased or intensified. The Spanish conquest (0.4-0.2 ka BP) brought new political, technological, demographic, and land-use conditions which changed the socio-environmental systems of the Atacama Desert. A proto-capitalist regime was introduced, focusing on the exploitation of raw materials, particularly minerals, which have dramatically stressed the human-environment relationships until today.

\section{Discussion}

The scale, intensity and continuity of human adaptive strategies in relation to fluctuating ecosystem resources have been diverse and variable throughout the last $14 \mathrm{ka} \mathrm{BP}$ in the Atacama Desert. Major humid or dry periods impacted the socio-environmental systems of hunter-gatherers, as well as the human occupation and the use of resources. Around 3 ka BP, a new, though less-intense, pulse of increased rainfall in the highlands reactivated ground-and surface-water flow in the hyperarid core of the Atacama. This boosted the development of complex water management technologies, and new social and ideological structures featured by the proliferation of people in the PdT. These innovations were also triggered by internal socio-cultural factors, which were capitalized by some communities in the PdT (e.g. Caserones village). The end of the wet period during the late Holocene (1.0-0.7 ka BP) led communities from the highlands and the coast to enlarge and improve novel systems of land use and management in the PdT. A new socio-political order dominated by segmented societies developed and lasted until the Inca epoch. This scenario was the base of the colonial and republican historical processes which accelerated the exploitation of desert environment resources. Both the environmental fluctuations and the people decisions based on cultural and social interests should be considered to explain the full range of complex sociopolitical variability in the PdT throughout the prehistory in the Atacama Desert.

\section{ACKNOWLEDGEMENTS}

CONICYT/PIA grant project ANILLO SOC1405.

\section{AFFILIATIONS}

${ }^{1}$ Centro de Estudios Avanzados en Zonas Áridas, Universidad de La Serena, Chile 2Instituto Alta Investigación, Universidad de Tarapacá Arica, Chile

${ }^{3}$ M. Uribe, M.E. de Porras, J. Capriles, E.M. Gayó, D Valenzuela, D. Angelo, C. Latorre, P.A. Marquet, A. Domic, V. McRostie, V. Castro

\section{CONTACT}

Antonio Maldonado: amaldonado@ceaza.cl

\section{REFERENCES}

Castro V et al. (in press) Chungara 48

Gayo EM et al. (2012) Earth Sci Rev 113: 120-140

Gayo EM et al. (2015) Quat Int 356: 4-14

Ledru MP et al. (2013) Holocene 23: 1545-1557

Maldonado A, Uribe M (2015) In: Retamal MS et al. (Eds) Actas del XIX Congreso Nacional de Arqueología Chilena. Sociedad Chilena de Arqueología, 193-200

Marquet PA et al. (2012) PNAS 109: 14754-14760

Núñez L et al (2013) Quat Int 307: 5-13

Pintar E (2014) Chungara 46: 51-71

Quade J et al. (2008) Quat Res 69: 343-360

Santoro CM et al. (2016) In: Aldunate C et al. (Eds)

Prehistoria en Chile desde sus Primeros Habitantes hasta los Incas. Editorial Universitaria, Santiago

Santoro CM et al. (in press) J Anthropol Archaeol, doi: 10.1016/j.jaa.2016.08.006

Urbina S et al. (2012) Bolet Museo Chile Arte Precolombino 17: 31-60

Uribe M (2006) In: Lechtman H (Ed) Esferas de Interacción Prehistóricas y Fronteras Nacionales Modernas: Los Andes Sur Centrales. Instituto de Estudios Peruanos e Institute of Andean Research, 449-502

Zori CM, Tropper P (2010) Bolet Museo Chile Precolombino 15: 65-87 